\title{
Melanochelys tricarinata (Blyth 1856) - Tricarinate Hill Turtle, Three-Keeled Land Turtle
}

\author{
INDRANEIL DAS ${ }^{1}$ \\ ${ }^{1}$ Institute of Biodiversity and Environmental Conservation, \\ Universiti Malaysia Sarawak, 94300 Kota Samarahan, Sarawak, Malaysia.
} [idas@ibec.unimas.my]

Summary. - The tricarinate hill turtle, Melanochelys tricarinata (Family Geoemydidae), is a small (carapace length to $\mathbf{1 7 4} \mathbf{~ m m}$ ), entirely terrestrial turtle from the deciduous and evergreen forests and riverine grasslands of the northern Indian subcontinent. The species appears to be rare, and is poorly known. One to three eggs are laid at a time, nesting occurring during the winter months in Assam, northeastern India. A fibrous, soft-tissue connection between the plastron and carapace develops in adult females, allowing the passage of the large eggs. Eggs measure 38-47 x 23-27 mm, and incubation period is 60-72 days, hatching taking place in February, April, and May. Hatchlings measure 33-40 $\mathbf{~ m m}$ in carapace length.

Distribution. - Bangladesh, India, Nepal. Distributed in a relatively narrow sub-Himalayan band across northeastern India, southern Nepal, and northern Bangladesh.

Synonymy. - Geomyda tricarinata Blyth 1856, Geoemyda tricarinata, Chaibassia tricarinata, Nicoria tricarinata, Melanochelys tricarinata, Chaibassia theobaldi Anderson 1879, Nicoria tricarinata sivalensis Lydekker 1889, Nicoria sivalensis.

SubSPECIES. - None.

Status. - IUCN 2008 Red List: Vulnerable (VU B1+2c) (assessed 2000); CITES: Appendix I; Indian Wildlife (Protection) Act: Schedule I.

Taxonomy. - Melanochelys tricarinata was originally described as Geomyda tricarinata by Blyth (1856) and corrected to Geoemyda by Gray (1870). Subsequently, a synonym, Chaibassia theobaldi, was described by Anderson (1878). Boulenger (1889) recognized both tricarinata and theobaldi as congeners within Chaibassia. Usage of the generic name Geoemyda persisted until 1964, when McDowell (1964) split up the genus, and placed both G. tricarinata and G. trijuga in Gray's 1869 genus Melanochelys; although, he mentioned that he had never examined tricarinata. No subspecies have been described, and geographic variation, if any, remains undocumented.

Description. - The carapace is elongated, strongly arched, with relatively flat, sloping sides. The carapace is tricarinate, the vertebral keel being by far the most prominent, with the lateral keels serving to demarcate the ridge at which the nearly horizontal vertebral area joins with the much more nearly vertical flanks. The rim of the carapace is smooth,

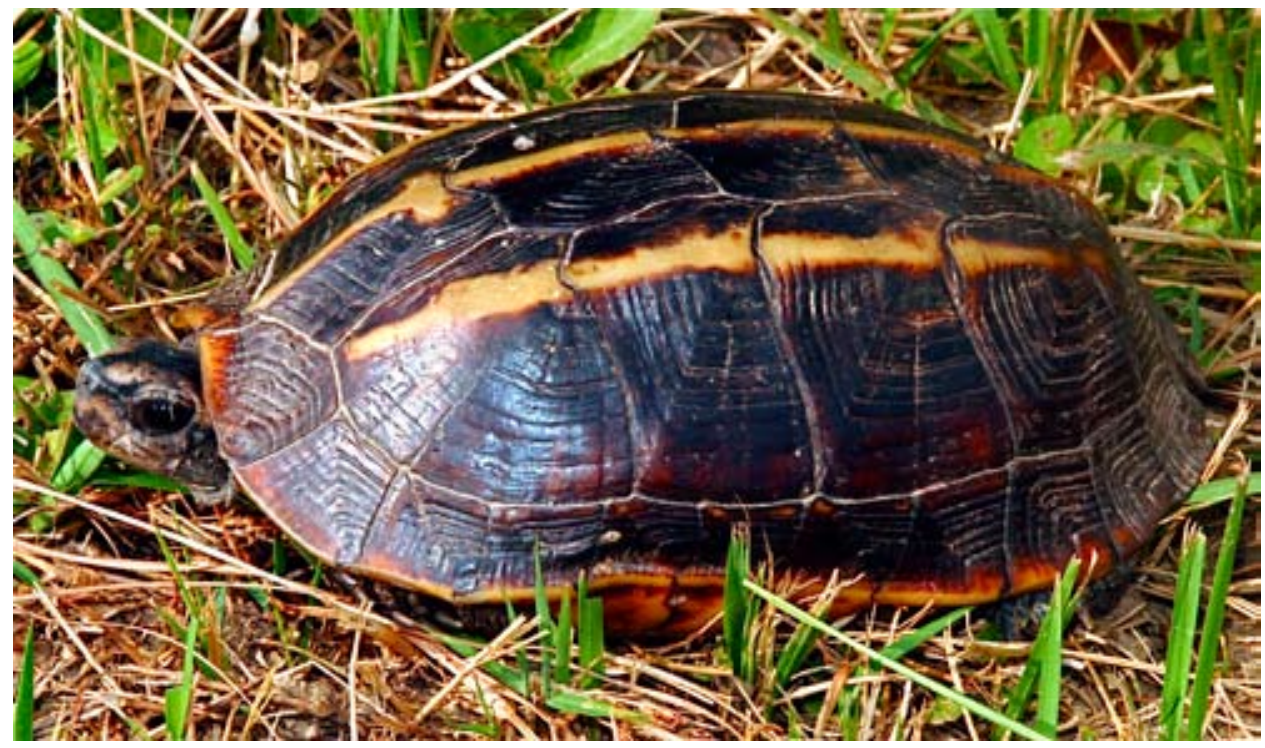

Figure 1. Melanochelys tricarinata, Dehradun, Uttaranchal, India. Adult female. Photo by Indraneil Das. 


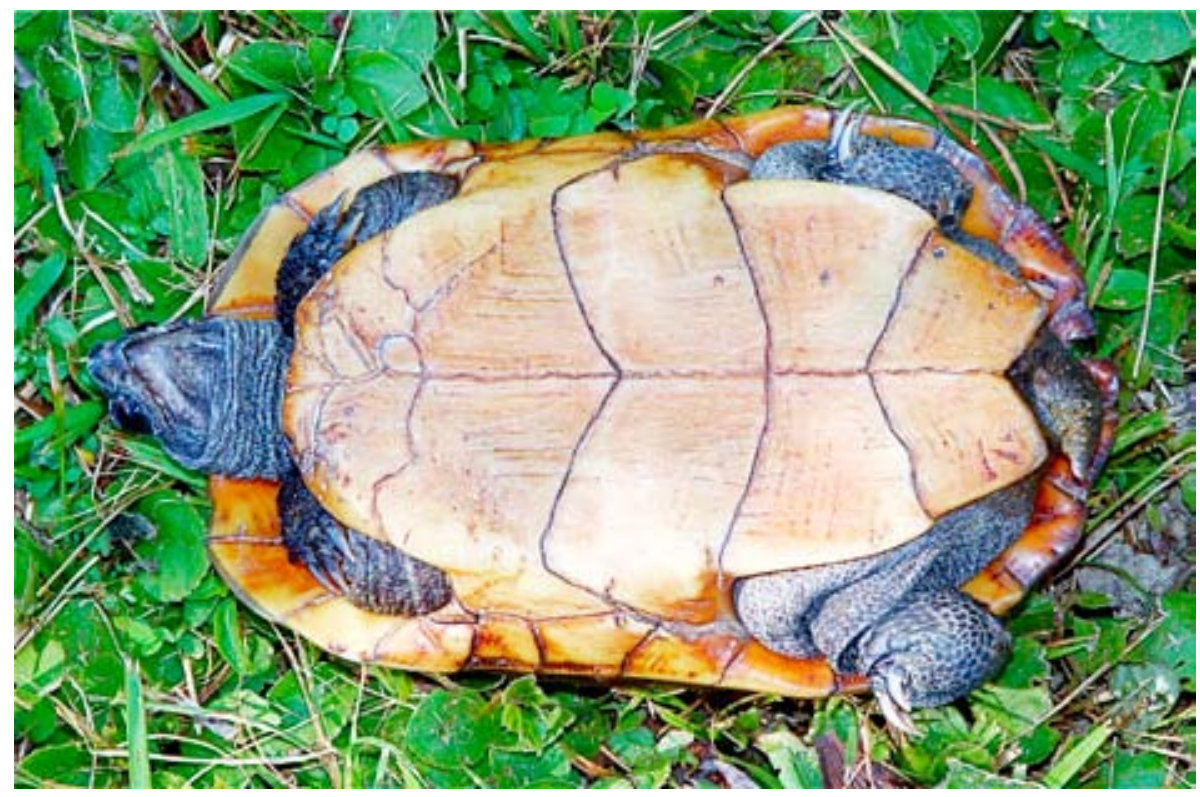

Figure 2. Melanochelys tricarinata, Dehradun, Uttaranchal, India. Adult female. Photo by Indraneil Das.

lacking serrations or scalloping. The nuchal scute is small and arrow-shaped in dorsal aspect. Vertebral scutes I-IV are all relatively broad towards the front, and are all narrower than the costal scutes. The areolae of all the carapace scutes remain contiguous with the posterior margin of the scute throughout life, except for vertebral 5 in which the areola remains approximately centrally located on the scute.

The plastron is long, usually as long as the carapace, and notched posteriorly. The hind plastral lobe is narrower than the shell opening, and longer than the width of the bridge. The longest median suture is between the pectorals or the abdominals, and the shortest between the humerals or the femorals. Axillary scutes are usually present, whereas inguinals are usually missing. Females have a fibrous connection between the hypoplastra and the carapace. The anterior digits are half webbed, the posterior digits virtually unwebbed. The outer surfaces of the forelimbs have enlarged, squarish, somewhat pointed scales. The snout is short, and the upper jaw feebly notched. The carapace is dark olive, gray-black,

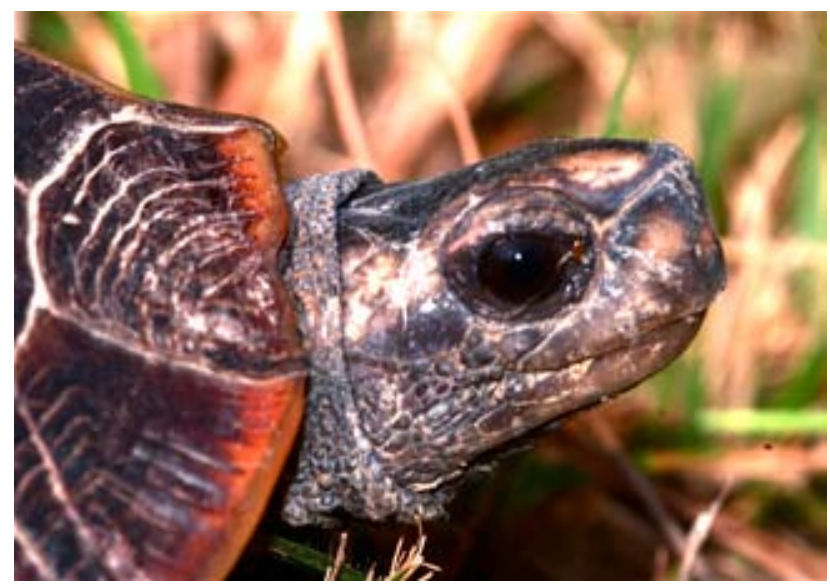

Figure 3. Melanochelys tricarinata, Dehradun, Uttaranchal,India. Adult female. Photo by Indraneil Das. or reddish brown, with pale yellow keels. The plastron is yellow or orange; the head and neck are gray black. A yellow or red stripe is sometimes present, extending from the nostrils, across the eyes, to the neck.

Some osteological details are given by Tikader and Sharma (1985). The skull has slender, thin, and incomplete temporal arches. The alveolar surfaces of the jaws are narrow, without a median ridge. The choanae are on a level with the anterior portion of the orbits. In the carapace, the second neural is typically octagonal, with the succeeding neurals hexagonal with the short sides posterior.

The species reaches $174 \mathrm{~mm}$ in straight carapace length (CL). Adult males have concave plastra, as well as relatively longer, thicker tails than females, but sexual size dimorphism remain unstudied. The karyotype is unknown, and no genetic phylogeographic analysis has been done.

Distribution. - The species is restricted to the northern parts of the Indian subcontinent, its distribution extending from Uttar Pradesh, in the Garhwal Himalayas of India, eastward through the rest of northern India, southern Nepal, and northern Bangladesh, to Arunachal Pradesh, in northeastern India (Das 1991; Busack 1994). The general distribution appears to be along the Himalayan foothills, although the disjunct records of the species from Chaibassa, in southern Bihar, India (Das 1991) and the Whykong Reserve Forest, Cox's Bazar District, Bangladesh (Khan 1987) are a considerable distance away from the hill ranges associated with the Himalayas. Mitchell and Rhodin (1996) summarized data on the occurrence of the species in Nepal, where the available records were only from Chitwan; Schleich and Kästle (2002) provided several more localities from the Terai (grassland plains at the foot of the Himalayas) of southwestern Nepal.

Habitat and Ecology. - This species is entirely terrestrial, utilizing moist deciduous (especially sal, Shorea robusta) and evergreen forests, in addition to riverine 


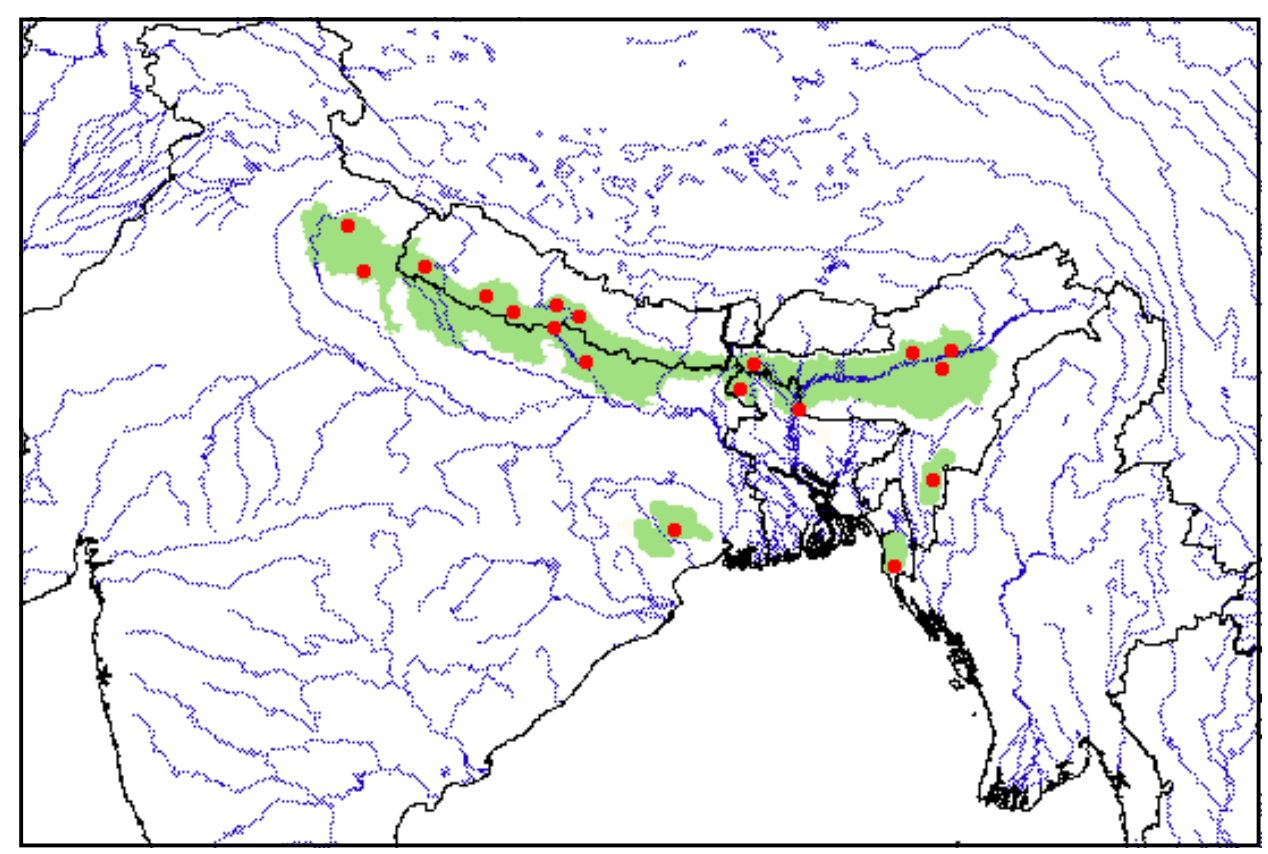

Figure 4. Distribution of Melanochelys tricarinata in the Indian subcontinent. Red points = museum and literature occurrence records based on Iverson (1992) plus more recent and author's data; green shading = projected distribution based on GIS-defined hydrologic unit compartments (HUCs) constructed around verified localities and then adding HUCs that connect known point localities in the same watershed or physiographic region, and similar habitats and elevations as verified HUCs (Buhlmann et al., unpubl. data), and adjusted based on author's data.

grasslands. Its habitat includes the Terai in the foothills of the Himalayas, and also lowland and primary forests in the midhills in eastern India and Bangladesh.

Virtually nothing is known about its ecology and behavior in the wild. Captives are crepuscular, spending the day in retreats in the leaf litter, under fallen tree trunks or tree buttresses. A male in captivity was active during the day in the early parts of the southwest monsoons, suggesting that courtship and mating in the wild may take place during the monsoons. When first caught, turtles of this species do not exude odiferous musk as do specimens of their congener Melanochelys trijuga, but they may defecate freely, in the same manner as many tortoises of the family Testudinidae (Das 1991).

Two captive females at the Manas Tiger Reserve, Assam, eastern India, laid a single large egg each on the open ground in December (Das 1988), and Theobald (1876) had noted a clutch of three eggs, each measuring 44.4 x 25.4 $\mathrm{mm}$. Anderson (1879) drew attention to the fibrous tissue connection between the hypoplastron and the carapace of females, which makes the shell slightly kinetic, presumably to allow the passage of its large eggs. This character is present in females of several geoemydid species, and is most developed in relatively small, terrestrial forms that lay proportionately very large eggs (e.g., Heosemys spinosa). Tikader and Sharma (1985) reported that 3 to 6 eggs are laid in a single clutch, and they illustrated a clutch of three eggs. Valentin and Gemel (1999) reported egg laying in captivity in the months of January-April, and between October-December, all coinciding with the dry season in the wild. Eggs measured 38-47 x 23-27 mm, and mass was $10-18 \mathrm{~g}$. The incubation period was $60-72$ (average 70 ) days at temperatures of $26-31^{\circ} \mathrm{C}$. Hatching occurred in the months of February, April, and May, in the dry and beginning of the wet season. Hatchlings had a CL of 33-40 mm.

Few data on growth rates are available, although the shells of adults often show excellent growth annuli. An animal with $147 \mathrm{~mm}$ CL in the Pritchard collection appears to have been eight years old. Mitchell and Rhodin (1996) examined annuli of a three-year old specimen from Chitwan, Nepal, and calculated that the hatchling CL had been $41 \mathrm{~mm}$, reaching $56.8 \mathrm{~mm}$ at one year, $72.5 \mathrm{~mm}$ at two years, and $82.0 \mathrm{~mm}$ at three years. Valentin and Gemel (1999) presented growth data on captives they maintained: a hatchling with $38 \mathrm{~mm}$ CL attained a size of $85 \mathrm{~mm}$ in $2.6 \mathrm{yrs}$, while one with a CL of $34 \mathrm{~mm}$ grew to $80 \mathrm{~mm}$ in the same time period.

Population Status. - No information available. The species appears to be rare even within protected areas in India, although B.C. Choudhury (pers. comm.) reported that it was relatively common in the Dehradun area of Uttaranchal State, India. In Bangladesh, this species is reported to be rare (Rashid and Khan 2000).

Threats to Survival. - Destruction of primary forests along the plains of the Ganga and Brahmaputra rivers may be responsible for the curious and apparently disjunct distribution of the tricarinate hill turtle. The species is exploited by the Chakma tribesmen of Bangladesh, and perhaps also by the aboriginals of northeastern and eastern India. Fires set in grasslands and deciduous forests as a park management procedure in many Indian wildlife reserves are suspected to be detrimental to this small surface-dwelling turtle. However, this may be a somewhat complex situation, since deliberate fire suppression sometimes leads to delayed but, ultimately, much hotter and more destructive fires. 
Fugler (1984) wrote that this species was not exploited in Bangladesh, but Khan (1987) heard reports of exploitation by the Chakma tribesmen of southeastern Bangladesh.

Tikader and Sharma (1985) reported that the main threats to this species in India included large-scale exploitation of eggs and adults for food by local tribal people; although collection of large numbers of eggs, at least, seems improbable in that the clutch size is so small. Choudhury and Bhupathy (1993) reported subsistence utilization of this species in Assam and Bihar, but did not record commercial use. Javed and Hanfee (1995) reported subsistence use within Dudhwa National Park, in northern India.

In Nepal, where this species is listed as an uncommon resident, it is considered very auspicious to encounter a specimen on national festival days (Shrestha 1996a). This author also recorded M.tricarinata as one of the species kept in Hindu temples in Nepal, where it is considered to be an incarnation of Lord Vishnu. Shrestha (1997) reported that the species is purely terrestrial, and found in the Narayani and Bagmati watersheds in Nepal, where it is threatened by habitat modification, pollution, and draining of swamps. In addition, the eggs are taken by hill tribes.

Mitchell and Rhodin (1996) found M. tricarinata to be commonly used for souvenir curio masks in temples and tourist facilities in Kathmandu, Nepal, finding 22 masks ( $18.3 \%$ of the total examined) made from this species. Masks were offered for sale for the equivalent of about \$US 6 each. The masks were reportedly manufactured in Bodhnath, close to Kathmandu, and the turtles themselves (or their shells) were brought from the southern Terai of Nepal, and possibly adjacent areas of northern India. Similar masks, reportedly fashioned in Tibet, are sold in Bangkok, Thailand (Das 1995).

Conservation Measures Taken. - The tricarinate hill turtle is listed on Schedule I of the Indian Wildlife (Protection) Act of 1972, Schedule III of the Bangladesh Wildlife (Preservation) Act of 1974, and Appendix I of CITES. This species has been reported from several protected areas in the region, including the Manas Tiger Reserve and Corbett National Park (both in India), the Royal Chitawan National Park (Nepal), and the Whykong Reserve Forest (Bangladesh). It is listed in the Red Data Book of Nepal (Shah and Tiwari 2004). It is classified as Vulnerable on the 2008 IUCN Red List.

Conservation Measures Proposed. - Surveys of isolated primary forest-clad hill ranges and riverine grasslands, especially in the far eastern and western parts of its range, may reveal unidentified populations of the species. Identified areas of occurrence need to be protected, possibly as reserves. Public education in areas where the species is consumed by local people may also be appropriate.

Captive Husbandry. - A single male of this species was maintained for a few years in an enclosure simulating natural conditions at the Madras Crocodile BankTrust. Fruits, vegetables, and fish were accepted by this specimen.Activities, including feeding, were mostly restricted to dusk.
Current Research. - A mark-recapture study to estimate population size is being conducted on the campus of Wildlife Institute of India, Dehradun (K. Vasudevan, pers. comm.). A survey of its status and distribution, and an autecological study of this species to understand specific conservation needs is necessary. A study to examine the possible effects of forest and grassland fire on wild populations of this species is also required.

Acknowledgments. - Supported by the Centre for Herpetology, Madras Crocodile Bank Trust, and Universiti Malaysia Sarawak. B.C. Choudhury and K. Vasudevan are thanked for unpublished information on the abundance of this species at Uttaranchal, and John Iverson and Peter C.H. Pritchard for comments on the manuscript.

\section{LITERATURE CITED}

Anderson, J. 1879. Anatomical and Zoological Researches: Comprising an Account of the Zoological Results of the Two Expeditions to Western Yunnan in 1868 and 1875; and a Monograph of the Two Cetacean Genera, Platanista and Orcella. Bernard Quaritch, London. Vol. I, 984 pp., Vol. II, 29 pp.

BLYth, E. 1856. Report for October Meeting, 1885. Proceedings of the Asiatic Society of Bengal 24:711-723.

Boulenger, G.A. 1889. Catalogue of the Chelonians, Rhynchocephalians, and Crocodilians in the British Museum (Natural History). British Museum (Natural History), London, 311 pp.

BusACK,S.D. 1994. Melanochelys tricarinata (tricarinate hill turtle). India: Uttar Pradesh. Herpetological Review 25:32.

Choudhury, B.C. And Bhupathy, S. 1993. Turtle Trade in India: A Study of Tortoises and Freshwater Turtles. World Wide Fund for Nature- India/TRAFFIC- India, New Delhi, 50 pp.

DAs, I. 1988. Turtles of Manas Tiger Reserve. Report to the Assam Forest Department, Guwahati, 5 pp.

DAs, I. 1991. Colour Guide to the Turtles and Tortoises of the Indian Subcontinent. R \& A Publishing Limited, Portishead, 133 pp.

DAs, I. 1995. Turtles and Tortoises of India. World Wide Fund for Nature- India/Oxford University Press, Bombay, 176 pp.

GraY, J.E. 1869. Notes on the families and genera of tortoises (Testudinidae) and on the characters afforded by the study of their skulls. Proceedings of the Zoological Society of London 1869:165-225.

Gray, J.E. 1870. Supplement to the Catalogue of Shield Reptiles in the Collection of the British Museum. Part I. Testudinata (Tortoises). London: British Museum, $120 \mathrm{pp}$.

Iverson, J.B. 1992. A Revised Checklist with Distribution Maps of the Turtles of the World. Richmond, IN: Privately printed, $363 \mathrm{pp}$.

JaVEd, S. AND HanfeE, F. 1995. Freshwater turtles of Dudhwa National Park and their conservation. Hamadryad 20:21-26.

KHAN, M.A.R. 1987. Bangladesher Bonnyoprani. Vol. I. Urochor o Shorishrip. Bangla Academy, Dhaka, 169 pp.

McDowell, S.B. 1964. Partition of the genus Clemmys and related problems in the taxonomy of the aquatic Testudinidae. Proceedings of the Zoological Society of London 143:239-279.

Mitchell, J.C. AND Rhodin, A.G.J. 1996. Observations on the natural history and exploitation of the turtles of Nepal, with life history notes on Melanochelys trijuga. Chelonian Conservation and Biology 2:66-72.

RASHID, S.M.A. AND KHAn, S.M.H. 2000. Overview of turtle trade in Cambodia. In: P.P. van Dijk, B.L. Stuart, and A.G.J. Rhodin (Eds.). Asian Turtle Trade: Proceedings of a Workshop on Conservation and Trade in Freshwater Turtles and Tortoises in Asia. Chelonian Conservation Monographs 2, pp. 77-85. 
Schleich, H.H. AND KäSTLE, W. 2002. Order Chelonia/Testudines (turtles: terrapins \& tortoises). In: H.-H. Schleich \& W. Kästle (Eds). Amphibians and Reptiles of Nepal. Biology, Systematics, Field Guide. Koeltz Scientific Books, Koenigstein, pp. 501-573.

SHAH, K.B. AND TIWARI, S. 2004. Herpetofauna of Nepal. A Conservation Companion. IUCN Nepal, Kathmandu, 237 pp.

Shrestha, T.K. 1996a. New survival of rare chelonians in the altered habitats of Himalayan rivers of Nepal: In: B. Devaux (Ed.). Proceedings of the International Congress of Chelonian Conservation. SOPTOM, Gonfaron, pp. 52-56.

SHRESTHA, T.K. 1997. Status, biology, and management of tortoises and turtles in the Himalayan foothills of Nepal.In: J. Van Abbema (Ed.). Proceedings: Conservation, Restoration, and Management of Tortoises and Turtles- An International Conference. New York Turtle and Tortoise Society, New York, pp. 278-286.

Theobald, W.1876. Descriptive Catalogue of the Reptiles of British India. Thacker, Spink and Company, Calcutta, 238 pp.
TiKader, B.K. and Sharma, R.C. 1985. Handbook: Indian Testudines. Zoological Survey of India, Calcutta. 156 pp.

VALENTIN, P. AND Gemel, R. 1999. Zur Fortpflanzungsbiologie der Dreikel-Erdschildkröte Melanochelys tricarinata (Blyth, 1856) (Testudines: Bataguridae). Herpetozoa 12(3/4):99-118.

\section{Citation Format for this Account:}

DAS, I. 2009. Melanochelys tricarinata (Blyth 1856) - tricarinate hill turtle, three-keeled land turtle. In: Rhodin, A.G.J., Pritchard, P.C.H., van Dijk, P.P., Saumure, R.A., Buhlmann, K.A., Iverson, J.B., and Mittermeier, R.A. (Eds.). Conservation Biology of Freshwater Turtles and Tortoises: A Compilation Project of the IUCN/SSC Tortoise and Freshwater Turtle Specialist Group. Chelonian Research Monographs No. 5, pp. 025.1-025.5, doi:10.3854/crm.5.025.tricarinata.v1.2009, http://www.iucn-tftsg.org/cbftt/. 